\title{
THE LOOSE UNIVERSITY-INDUSTRY CONNECTION AND THE STUDENTS' MISCONCEPTION ABOUT THEIR EMPLOYABILITY
}

\author{
Thi Tuyet Tran \\ Institution for Employment Research, German Federal Employment Agency, Germany \\ Vietnam National University, Hanoi, Vietnam \\ Email: Thi-tuyet.tran@iab.de
}

\begin{abstract}
Although training high skilled labour force for the industry is considered one of the central missions of the higher education training in Vietnam, there is a popular claim in the literature about the disappointment among employers about the work-readiness of university graduates. One of the critical influencing factors is students' perception about their 'assets' for employment, as this will determine their actions and decide their employability. This study investigates and compares the perspectives of employers and students on the issues of students' employability assets. The research findings were drawn from a mix method research project. The analysis of the quantitative data revealed that while both employers and students shared a common perception on the important assets of employability in the Vietnamese workplace, their evaluation of these assets differed significantly. The students appeared more confident with the acquired knowledge and skills, however, the employers seemed to be critical about, and not satisfied with the employability assets students possessed at the point of recruitment after graduation. The lack of practical experience and the poor understanding about the real needs of the labour market among students was found in the qualitative interviews as the major reasons for that low level of satisfaction among employers. There is an urgent call for a better connection between universities and enterprises in order to bring about more up-to-date and practical lessons for students. University-industry collaboration activities need to be in place to stop students from wobbling around to find their ways to employment.
\end{abstract}

Keywords: Graduate Employability, Higher Education, Misconception, University-industry Collaboration, Vietnam.

\section{Introduction}

Due to the mass higher education and the call for the responsiveness of higher education institutions in the competitive knowledge economy, employability has become in vogue in the higher education context. Universities have tried to enhance knowledge and skills for their students with the expectation that the students will satisfy the needs of employers and will be work-ready at the point of graduation. Nonetheless, the effort does not always work and the term 'employability' sometimes means differently in the different eyes of the stakeholders. In Vietnam, where training high skilled labour force for the industry is considered the central mission of the higher education system (HES), the call for the university's responsiveness to the needs of the labour market is often loud (Tran Ngoc Ca, 2006; Tran Quang Trung \& Swierczek, 2009; Tran Thi Tuyet, 2013). Nonetheless, Vietnamese universities do not seem to implement this mission successfully, given the fact that the number of graduates ending up unemployed has increased alarmingly. In 2010, the number of unemployed higher education graduates aged from 21 to 29 was less than 60,000 (about 6.84\%). However, despite the fact that the number of students enrolling in the system has remained rather stable since 2010 (MOET, 2013), in 2013, 
the number of unemployed graduates had increased to 101.00o (9.89\%) (Ngoc Hà, 2013), then climbed to 225,500 in the first quarter of 2015 (Ministry of Labor - Invalids and Social Affairs \& General Statistics Office, 2015), and reached 324,700 in 2016 (Ministry of Labor - Invalids and Social Affairs \& General Statistics Office, 2016). In fact, the representative of the General Statistics Office also admitted that the real number of university graduates who could not use their knowledge and skills acquired at the universities should be much higher as these surveys did not distinguish the types of work graduates were doing, so they would be counted as employed even when they only conducted simple manual work (Ngọc Hà, 2013).

Clearly, Vietnamese higher education is weak in providing students with knowledge and skills required by the contemporary employers. When explaining the reason for the trend of sharply increasing in number of unemployed graduates, the Ministry of Education and Training (MOET) admits that the low quality of training, especially in the local and community colleges and universities, with the poor teaching and learning infrastructure, the lack of qualified teaching staff and the low competitiveness in training and providing skilled labour force for the industry make it hard for students to find jobs in the labour market (VOV1 News, 2015). Nonetheless, the loose connection between the HES and the labour market has also contributed much to the worrying trend of students ending up unemployment after graduation. While it is popular belief that it is students' onus to develop their employability (Leong \& Kavanagh, 2013; McQuaid \& Lindsay, 2005; Tan \& French-Arnold, 2012; Van Buren III, 2003), what students can get access to during the time at university shapes their perception about what should be considered as important and how they should do to develop their assets for employment. These, in turn, determine their actions, and then, decide their employability when negotiating their transition to the employment market.

This paper aims to investigate students' perception of the necessary employability assets they need to prepare and develop before entering the labour market. It also wants to explore how students evaluate their own 'assets' for employment. This will be put together with the employers' perception about the same issues. The comparison between the 'supply side' and the 'demand side' hopefully will bring about a clearer picture of the gap between the two, and possible ways to bridge that gap.

\section{Literature review}

Employability is often viewed as the fitness or the suitability of graduates for the labour market. Yorke (2010), for example, considers employability as the ability of graduates to find and retain a graduate-level job and also the ability to move between jobs if required. More specifically, employability is defines as:

a set of achievements, understandings and personal attributes that make individuals more likely to gain employment and be successful in their chosen occupations (Knight \& Yorke, 2004, p. 9). Artess, Forbes and Ripmeester (2011) suggest that there is an underlying consensus as to what employability comprises - a range of specific, employment-related skills or attributes relevant to acquiring and succeeding in employment. Employability has been immerged in the higher education context as a response of higher education to some practical requirements. These may include the increase demand and expectation of fee-paying students and their family for their value-for money investment in education; the increase pressure from the government for an efficient higher education industry in relation to the development of human capital for a 
competitive knowledge economy; and the increase number of unemployed graduates (Kinash et al., 2014; Tran Thi Tuyet, 2015).

The increased number of these young skilled workers is a worrying trend. It is a waste of productive resources (Brada, Marelli, \& Signorelli, 2014), a failure of investment made by students and their family on higher education (Kinash et al., 2014). It is also a loss of human capital investment. This will negatively affect long-run growth and productivity of the market. For individual graduates, being not able to successfully negotiate transition to employment prevents them getting access to individual valuable benefits that they would enjoy if employed, such as financial independence, social networks or self-esteem (Tilbury, Creed, Buys, \& Crawford, 2011). Unemployment prevents the accumulation of work experience, and this certainly creates negative effects on individual income and future career possibilities (Brada et al., 2014), and more seriously, it increases the risk of these young people being excluded from the labour market for the long term (Bell \& Blanchflower, 2011). Thus, there is a pressing call from the government as well as from all other stakeholders for universities to enhance employability for students, and to make sure that students are work-ready at the point of graduation. Many higher education systems worldwide have also gradually taken employability on board.

Nonetheless, not all of the employability skills can be developed solely in the higher education context. In order to enhance employability for students, enhance employment-related skills or attributes, or in other words, enhance the skills necessary for graduates to get and retain jobs, employers' involvement is necessary. University is where to develop students' graduate employability, however, the results of that development can only be seen in enterprises (Tran Thi Tuyet, 2016). Tran Thi Tuyet (2016) also argues that if higher education wants to enhance employability for its students, input and collaboration from the industry is essential. Students need to be engaged in meaningful work while learning because the skills helping graduates to retain their job and develop in their career will mainly be developed in the working context and are mainly the outcome of enterprise learning (Owens \& Tibby, 2014; Weligamage, 2009).

Work integrated learning (WIL) or 'the process of bringing together formal learning and productive work, or theory and practice' (Cooper, Orrell, \& Bowden, 2010, p. viii) with the collaboration between university and industry aiming at enhancing graduate employability has been adopted in many countries such as the UK, the US, Canada, Australia and some European countries. This has marked the effort of universities in enhancing students' experiential learning by developing/adopting work placements and internships, work-based learning, sandwich course, service learning in the curriculum design. Similarly, employer commitment and engagement in developing student employability has also been evident by getting involved in curriculum design, course design, development and implementation. Industry representatives have also been more popular in the university director board, or in delivery of guest lectures.

Both experiential learning initiatives and employers engagement in the university practices work for the same aim: to help and also to require students to integrate theory and practice (Cooper et al., 2010; Ferns, Campbell, \& Zegwaad, 2014; Ferns \& Moore, 2012; Smith, Meijer, \& Kielly-Coleman, 2010). Furthermore, by providing educational programs which combine and integrate learning and workplace application, WIL places students in the role of workers to develop 'implicit tacit knowledge about their practice and surfacing this knowledge through reflection' (Smith et al., 2010, p. 2). This will improve students' work readiness and competitiveness and reduce employers' time and funding spent on training new staff (Elder, 
2014; Tran Thi Tuyet, 2014). Ultimately, students university-industry collaboration and WIL practices are not only beneficial for students and their career prospects but is also reported to bring benefits for all related stakeholders, including higher education institutions, employers and society.

In Vietnam, although training high skilled labour force for the industry is considered a central mission of the HES, the collaboration between universities and the enterprises to enhance graduate employability is still considered to be at its very early stage of development. The impact of this cooperation is often very modest as it is very usual to hear the complaint from the university about the lack of industry input for their curriculum development and delivery (Huynh Ngoc Long, 2012). However, when it comes to the employers' view, there seems to be another picture drawn about the collaboration between universities and enterprises. There is a growing number of employers, who understand the importance of their input from the early stage of skill development and are open for collaboration with universities for human resource training. These employers also raise their voices complaining about their difficulties in communication with universities and in understanding universities' goal when students are sent to their organizations for internships or placements (Pham Thi Ly, 2013). The loose connection and the lack of mutual understanding has created more hurdles for the process of enhancing graduate employability in Vietnam.

\section{Research framework}

The research was designed to explore and compare the perception of students and employers about the important employability assets and their evaluation of these assets in the Vietnamese labour market. It is a mixed method study and was conducted in 2015 to seek the perspectives of both students and employers to answer the following research questions:

- What are important assets for graduate employability in Vietnam?

- How good are students' assets for employment?

Questionnaires were developed based on the findings of Tran Thi Tuyet's (2014) research on graduate employability in Vietnam. The study has developed based on the employability framework provided by Hillage and Polard (1998) and has identified the five most important graduate employability assets in the Vietnamese labour market, namely professional knowledge, the ability to apply the acquired knowledge in the specific context at work (applied knowledge), soft skills (the term used popular in Vietnam, the meaning is similar to generic skills or life skills), foreign language and work experience. Apart from these five components, social connection, money and family background are also considered important in enhancing employment opportunity for job seekers in the Vietnamese connectivist culture (Tran Thi Tuyet, 2014).

The two surveys were developed using an online interface (Google Docs survey) and sent to students via the Student Associations in different universities in Vietnam, and to employers via the Vietnam Chamber of Commerce and Industry. The valid answers were collected and analysed using SPSS data analysis software.

Two group interviews of eight students in each group and eight individual face to face interviews with employers were conducted to bring more insights to the quantitative findings and reasons behind any difference between students and employers' perceptions. 


\section{Findings}

\section{Perceptions about employability assets}

As seen in Figure 1, perceptions of employability of students and employers shared many similarities. Both considered applied knowledge (the term used to refer to students' capability to apply knowledge in the real context at work) is most important for any student who wants to be employable after graduation. The other four major 'components' or assets of employability, namely professional knowledge, soft skills (generic skills), foreign language and work experience, are also shared agreement by the two. Nonetheless, higher proportion of the students consider soft skills, foreign language and work experience essential for them to stay employable than the employers. On the other hand, the employers tend to evaluate professional knowledge and applied knowledge higher than the students (see details in Figure 2). Interestingly, only $12 \%$ of the employers named some other characteristics, i.e. 'good' work attitude, positive life style, or good behaviour as important in increase of chances for graduates to obtain employment, students named different other factors as necessary for them to negotiate their transition to employment. Specifically, more than a third of the student participants considered network (or the social connection that they had with the employment world) as an important component of employability, and about $15 \%$ of them considered money and offspring as decisive factors to decide their employability.

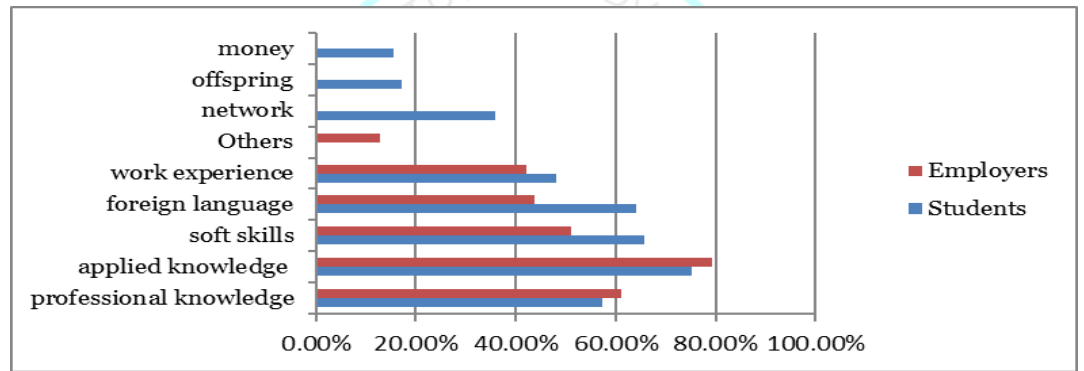

Figure 1: Students and employers' perceptions about employability

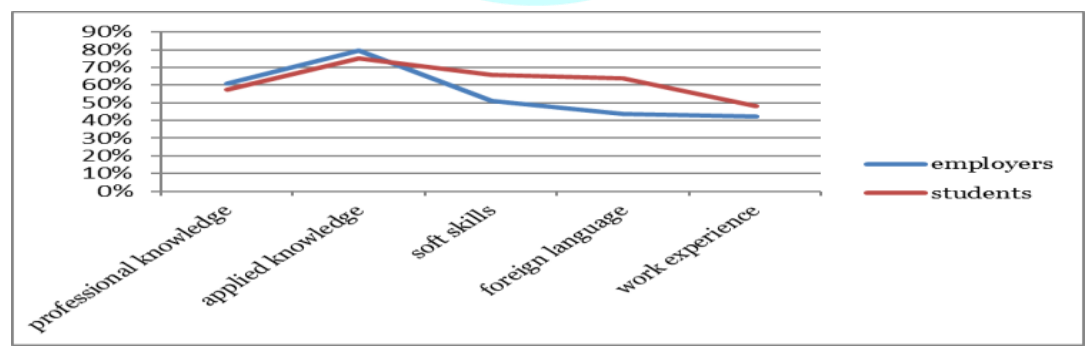

Figure 2: Key components of employability

\section{Evaluation of students' employability assets}

Although sharing similar perceptions about graduate employability assets, perspectives of students and employers were different significantly when it comes to their evaluation of the current employability assets of students. While more than half of the student participants were confident about the assets they had developed for employability (See Table 1), the majority of the employer participants showed their disappointment about what students could offer, the means of all the categories are below 3 (the 5 point Likert scale was used) (see Table 2). 
Asia Pacific Journal of Contemporary Education and Communication Technology

ISBN (eBook): 9780994365682 । ISSN : 2205-6181

Year: 2017, Volume: 3, Issue: 2

\begin{tabular}{|c|c|c|c|c|c|}
\hline & $\begin{array}{l}\text { Professional } \\
\text { knowledge }\end{array}$ & $\begin{array}{l}\text { Applied } \\
\text { knowledge }\end{array}$ & Soft skills & $\begin{array}{l}\text { Foreign } \\
\text { language }\end{array}$ & $\begin{array}{l}\text { Work } \\
\text { experience }\end{array}$ \\
\hline Frequency & 522 & 612 & 509 & 491 & 240 \\
\hline Percentage & $53.30 \%$ & $62.50 \%$ & $51.90 \%$ & $50.1 \%$ & $24.50 \%$ \\
\hline \multicolumn{6}{|c|}{ Table 1: The number of students' feeling confident about their employability assets } \\
\hline & $\begin{array}{l}\text { Professional } \\
\text { knowledge }\end{array}$ & $\begin{array}{l}\text { Applied } \\
\text { knowledge }\end{array}$ & Soft skills & $\begin{array}{l}\text { Foreign } \\
\text { language }\end{array}$ & $\begin{array}{l}\text { Work } \\
\text { experience }\end{array}$ \\
\hline $\mathbf{N}$ & 109 & 109 & 109 & 109 & 109 \\
\hline Mean & 2.48 & 2.74 & 2.85 & $2.7 O$ & 2.63 \\
\hline Mode & 2 & 3 & 3 & 3 & 3 \\
\hline
\end{tabular}

Table 2: Employers' evaluation of students' employability assets

Nonetheless, the figures from both students and employers are disappointing. Only about a half of the students suggested that they were confident about the employability assets that they could develop (Table 1). The lowest confidence was seen in work experience. Only about a quarter of the students considered themselves as having some form of relevant work experience that they could make use of when negotiating their transition to employment. This reflected the loose relationship between the theory training in higher education and the practical lessons from the world of work, as most students could not find an opportunity to conduct experiential learning to integrate theory and practice during university time. The means of all components in Table 2 are all below 3 - the average point of the evaluated scale - this also means that most employers dissatisfied with the employability assets that students possessed.

When comparing the proportion of the students who self-evaluated their employability assets as good and the proportion of students who, in the eye of the participating employers, possessed good employability assets, the gap was truly wide (See Figure 3). Although the patterns look somehow similar with both considered the applied knowledge capability of students was better than other assets, and work experience was the worst asset, the proportion of students who highly evaluated their assets was far higher than the proportion of students employers suggested to possess good employability assets. Specifically, while employers suggested that only around $10 \%$ and $20 \%$ of students obtained good professional knowledge and applied knowledge, these proportions in students' perception were more than $50 \%$ and $60 \%$ respectively. The follow-up interviews were designed to explore the reasons behind this wide gap.

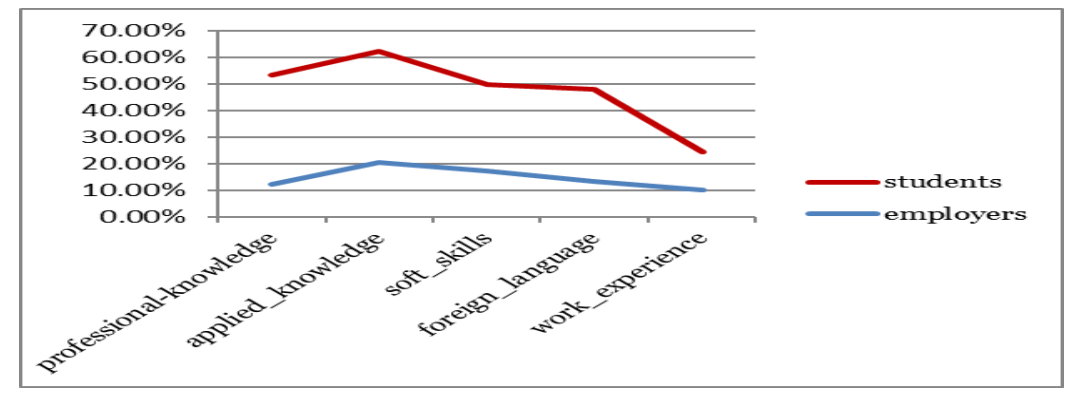

Figure 3: The proportion of students who possessed good employability assets in the eye of the students vs. Employers 


\section{What shaped students' and employers' perception about graduate employability}

When was asked, the majority of student interviewees suggested that they developed their perception about employability based mainly on the media and rumor around them. Most of the time, they started with: it is said that, people say that, or it is popular in the media that...Then they could name easily the essential employability components that employers looked for, but were struggling when were asked to explain what each component means. Most of the time they explained their understanding in a quite simple way, for example:

I've read online and known that all employers now require us to have soft skills like communication skills or presentation skills. I don't think university can help me to acquire these skills, so I go to a soft skill center to take some soft skills courses, and now I think I am quite confident with my soft skills!

Or:

Employability is what employers are looking for, that is professional knowledge, soft skills, work experience and English. When you open any job advert, you'll find the requirements for these things.

Nonetheless, some students also appeared to be more critical:

Employers all ask for our ability to apply knowledge in the real working context, but we don't know how the working context is. Most of our experience is related to our part-time jobs during university time and it often relates to tutoring or sale assistance - this is, most of the time, of no use for the employers.

Some other students blamed their poor understanding of the labour market on their universities:

You know, we have to study with old textbooks, then when we ask our teachers about the knowledge or books necessary for our job in the future, many cannot give us a good piece of advice. Most of them are just like us, young, and have just graduated from university and become lecturers; they also don't have any work experience outside. How do they know to teach us the thing the outside employers want?

Overall, students shared the point that they have to work out for themselves what was important for them to be employable in the future and how to develop their ways to achieve those assets. University was often of little help and employers were virtually absent in the curriculum.

When it comes to employers' opinions, all of the interviewees suggested that the majority of the students had unrealistic thinking about their employability assets. The problems rooted at their lack of practical experience. During most interviews, those words such as illusion (ảo tưởng), misconception (ngộ nhận), pure theory (sách vở , lý thuyết), lack of professionalism (thiếu tính chuyên nghiệp) were repeatedly used by the employers to speak about the students approaching them for jobs. One employer even divided students into three groups:

There are three typical types of students, some are quite dynamic, they worked during their study and had developed certain skills. Some lack practical experience and are too proud of themselves. The rest has only book knowledge which we cannot use...

Nonetheless, most employers admitted that one of the significant reasons which made students appear disqualified in the eye of the recruiters was that the working environment was too 'strange' to them. Recent graduates could not imagine the working context and culture in the 
labour market, some managed to be recruited but soon become crestfallen and sacked as they could not adjust themselves and adapt to the working requirements. Employers also suggested that some students were active and devoted, but what they lack was the practical lessons at work, this prevented students from transiting smoothly from university to the employment context.

\section{Discussion and Conclusion}

It becomes evident from the study that many Vietnamese students now understand that they need to be in charge of their employability and try to work hard to develop what their think the essential assets that can satisfy the requirements of employers. Although most of them could develop an understanding about the important components of employability in a quite similar way to the expectation of employers, the lack of practical experience prevents them from developing these assets the ways appreciated by the employers. The majority of the student participants appeared critical about their limited understanding and preparedness toward the requirements of the labour market. The lack of opportunities to integrate theory and practice, the irrelevant of work experience, the outdated curriculum in universities and the lack of guidance and support for their transition to the labour market had all created negative impacts on the process of enhancing graduate employability in Vietnam.

While both employers and students shared a common perception of the important employability assets in the Vietnamese workplace, their evaluation of the current employability assets of students differed significantly. Furthermore, while both students and employers appeared critical about the employability assets university students could develop/offer, students seemed to be more confident with the knowledge, skills and experience they could acquire and develop to satisfy employers. Employers, in contrast, appeared more critical about, and not satisfied with the employability assets students possessed at the point of recruitment after graduation. The gap between students' and employers' perceptions reflected the gap between university training and the labour market demand. These two stakeholders seemed to stand too far from each other. This finding supports Tran Thi Tuyet's (2015) claim that, in Vietnam, employers were virtually still absent in university curriculum design and delivery while universities were struggling to renovate their theory-oriented teaching curriculum.

Clearly, the limited exposure to the real context and requirements at work and the lack of opportunities to apply the learnt theories into practice had affected significantly on the way students adopted to develop their employability assets (Ferns et al., 2014; Smith et al., 2010), and evidence from this study suggests that this had created disappointment among students when they thought they prepared well for employment but were not appreciated by the employers. On the other hand, employers kept complaining about the students' illusion, misconception and lack of practical experience when approaching jobs after graduation.

There is an urgent call for a better connection between universities and enterprises in order to bring about more up-to-date and practical lessons for students. MOET and universities should focus their resource on initiatives such as work integrated learning, placements and internships and organize these programs in effective ways to help students develop a better understanding about the labour market. University-industry collaboration activities need to be in place to stop students from wobbling around to find their ways to employment. 


\section{References}

i. $\quad$ Artess, J., Forbes, P. \& Ripmeester, N., 2011. Supporting graduate employability: HEI practice in other countries, London: BIS.

ii. Bell, D. \& Blanchflower, D., 2011. Young people and the Great Recession. Oxford Review of Economic Policy, 27(2), pp. 241-267.

iii. $\quad$ Brada, J., Marelli, E. \& Signorelli, M., 2014. Introduction: Young People and the Labor Market: Key Determinants and New Evidence. Comparative Economic Studies, 56(4), pp. 556-566.

iv. $\quad$ Ca, T. N., 2006. Universities as drivers of the urban economies in Asia: The case of Vietnam. Policy Research Working Paper, s.l.: World Bank.

v. Cooper, L., Orrell, J. \& Bowden, M., 2010. Work integrated learning: A guide to effective practice. New York: Routledge.

vi. Elder, S., 2014. Labour market market transition of young women and man in Asia and the pacific, Geneva: International Labour Office.

vii. $\quad$ Ferns, S., Campbell, M. \& Zegwaad, K., 2014. Work integrated learning. In: S. Ferns, ed. Work Wintegrated learning in the curriculum. Milperra: Higher Education Research and Development Society of Australasia HERDSA, pp. 1-6.

viii. $\quad$ Ferns, S. \& Moore, K., 2012. Assessing student outcomes in fieldwork placements: an overview of current practice. Asia-Pacific Journal of Cooperative Education, 13(4), pp. 207-224.

ix. Hà, N., 2013. Tốt nghiệp càng nhiê u, thâ't nghiệp càng cao (The more graduated, the more unemployed).

[Online] Available at: http://tuoitre.vn/tin/giao-duc/20131226/totnghiep-cang-nhieu-that-nghiep-cangcao/587168.html [Accessed 14 October 2015].

x. Hillage, J. \& E.Pollard, 1998. Employability: Developing a framework for policy analysis. London: Department for Education and Employment.

xi. III, H. V. B., 2003. Boundaryless careers and employability obligations. Business Ethics Quarterly, 13(2), pp. 131-149.

xii. $\quad$ Kinash, S. et al., 2014. Global graduate employability research: A report to the Business2o Human Capital Taskforce Gold Coast. QLD Australia: Bond University.

xiii. Knight, P. \& Yorke, M., 2004. Learning, curriculum and employability in higher education. London: Routledge Falmer.

xiv. $\quad$ Leong, R. \& Kavanagh, M., 2013. A work-integrated learning (WIL) framework to develop graduate skills and attributes in an Australian university's accounting program. Asia-Pacific Journal of Cooperative Education, 14(1), pp. 1-14.

xv. Long, H. N., 2012. Đào tạo đáp úng nhu cầu thị trường lao động (Training for the employment market). Paper presented at the Đào tạo, nghiên cúu khoa học và chuyển giao công nghệ gắn kết vói nhu cầu doanh nghiệp (Training, research and technology transfer vs enterprise deman. Vietnam: Dong Nai.

xvi. Ly, P. T., 2013. Quan điểm của doanh nghiệp vê` hợp tác với các trường đại học ở Việt Nam. In: M. o. E. a. Training, ed. Enterprises' perspective of the collaboration with universities in Vietnam, POHE Project . Hanoi: Ministry of Education and Training.

xvii. McQuaid, R. \& Lindsay, C., 2005. The concept of employability. Urban Studies, 42(2), pp. 197-219. 


\section{Asia Pacific Journal of Contemporary Education and Communication Technology \\ ISBN (eBook): 9780994365682 | ISSN : 2205-6181 \\ Year: 2017, Volume: 3, Issue: 2}

xviii. Ministry of Labor - Invalids and Social Affairs, \&. G. S. O., 2016. Newletter for Vietnam's Labour Market Update, Hanoi: Ministry of Labor - Invalids and Social Affairs.

xix. Ministry of Labor - Invalids and Social Affairs, \& General Statistics Office, 2015. Newsletter for Vietnam's Labour Market Update, Hanioi: Ministry of Labor - Invalids and Social Affairs.

xx. MOET, 2013. Thống kê $2013 \quad$ (2013 $\quad$ Statistics). [Online] Available at: $\quad$ http://www.moet.gov.vn/?page=11.11\&view $=5251$

[Accessed 14 October 2015].

xxi. Owens, J. \& Tibby, M., 2014. Enhancing employability through enterprise education:Examples of good practice in higer education, s.l.: The Higher Education Academy.

xxii. $\quad$ Smith, J., Meijer, G. \& Kielly-Coleman, N., 2010. Assurance of learning : The role of work integrated learning and industry partners. In: M. Campbell, ed. Work integrated learning : Responding to challenges. Perth, WA: Australian Collaborative Education Network (ACEN) Incorporated, Curtin University of Technology, pp. 409-419.

xxiii. Tan, L. \& French-Arnold, E., 2012. Employability of graduates in Asia: an overview of case studies. In: UNESCO, ed. Graduate employability in Asia. Bangkok: Graduate employability in Asia Pacific Regional Bureau for Education, pp. 1-4

xxiv. Tilbury, C., Creed, P., Buys, N. \& Crawford, M., 2011. The school to work transition for young people in state care: perspectives from young people, carers and professionals. Child and Family Social Work, 16(3), pp. 345-352.

xxv. Trung, T. Q. \& Swierczek, F., 2009. Skills development in higher education in Vietnam. Asia Pacific Business Review, 15(4), pp. 565-586.

xxvi. Tuyet, T. T., 2013. The perception of employability and the subsequent role of higher education in Vietnam. Journal of the World Universities Forum, 6(1), pp. 1-11.

xxvii. $\quad$ Tuyet, T. T., 2014. Graduate Employability in Vietnam: A Loose Relationship Between Higher Education and Employment Market. Hamburg: Anchor Academic Publishing.

xxviii. Tuyet, T. T., 2015. Is graduate employability the 'whole-of-higher-education-issue'?. Journal of Education and Work, 28(3), pp. 207-227.

xxix. Tuyet, T. T., 2016. Enhancing graduate employability and the need for university-enterprise collaboration. Journal of Teaching and Learning for Graduate Employability, 7(1), pp. 58-71.

xxx. VOV1 News, 2015. Tỷ lệ sinh viên ra trường "thâ't nghiệp" tăng 103\% (The rate of unemployed graduates increases 103\%). [Online] Available at: $\quad$ http://vovgiaothong.vn/xa-hoi/ty-le-sinh-vien-ra-truong-\%E2\%80\%9Cthatnghiep\%E2\%80\%9D-tang-103-/69839

xxxi. Weligamage, S., 2009. Graduates' Employability Skills: Evidence from Literature Review. Sri Lanka: University of Kelaniya.

xxxii. Yorke, M., 2010. Employability: aligning the message, the medium and academic values. Journal of Teaching and Learning for Graduate Employability, 1(1), pp. 2-12. 